\title{
Gyôri Zsolt
}

\section{„A mi agyunk téves kapcsolás": az új hullám találkozása az új érzékenységgel}

\begin{abstract}
Absztrakt
Jelen tanulmány az új érzékenység laza narratívájú filmjeit vizsgálja, amelyekben az 1980-as évek budapesti underground zenei szcénájának legjelentôsebb elôadói és zenekarai szerepelnek. Jacques Ranciére „az érzékelhetô felosztása” fogalmából kiindulva vizsgálja e filmek poétikáját és politikáját, amellett érvelve, hogy film és zene szinergiája nem csak a kulturális neoavantgárd irányzatokat, hanem egy alternatív nyilvánosságot és disszenzuális stratégiákat is elôtérbe helyezett. Elsôsorban A kutya éji dala, A pronuma bolyok története, az Ex-kódex, a Jégkrémbalett, az Eszkimó asszony fázik és a Rocktéritó címú filmekre támaszkodva a fejezet annak az érzékenységnek az újszerûségét és jelentéseit elemzi, amely az 1980-as évek morális nihilizmusát kifejezte, és az ellenállás ágenciáját megteremtette. Az érzékelhetô uralkodó felosztásának a könnyúzenei avantgárd/újhullámos zenekarok szövegvilágában is megjelenô destabilizálását az élô és rögzített zenét tartalmazó jelenetekben a színpadhasználatot, az elôadói mentalitást és a képnyelvi jellegzetességeket kiemelve elemzi a tanulmány.
\end{abstract}

\section{Szerző}

Gyốri Zsolt a Debreceni Egyetem Angol-Amerikai Intézetében adjunktus, itt szerezte PhD fokozatát is. Kiemelt kutatási területei közé tartozik a film és társadalom, a történelem és az emlékezet filmes ábrázolása, különös tekintettel a brit és a magyar filmtörténetre. A brit moziról antológiát (Fejezetek a brit film történetéból, 2010) szerkesztett, míg a rendszerváltás utáni magyar mozi kultúratudományos megközelítéseit kínáló kötetek (Test és szubjektivitás a rendszerváltás utáni filmben, Tér, hatalom és szubjektivitás viszonyai a magyar filmben, Nemek és etnikumok terei a magyar filmben) társszerkesztője. Filmek, szerzók, kritikai-klinikai olvasatok címú monográfiája 2014-ben jelent meg, a Travelling around Cultures: Collected Essays on Literature and Art szerkesztett kötete 2016-ban. A Hungarian Journal of English and American Studies folyóirat segédszerkesztôje. E-mail: gyorizs@yahoo.co.uk

https://doi.org/10.31176/apertura.2018.4.5 


\title{
Gyôri Zsolt
}

\section{„A mi agyunk téves kapcsolás”: az új hullám találkozása az új érzékenységgel}

\begin{abstract}
A budapesti underground zenei szcéna - bár a politikai enyhülés idôszakában kezdett kibontakozni - a kultúrpolitika vele szemben is maradéktalanul érvényesítette a $3 \mathrm{~T}$ (tû́rés, tiltás, támogatás) elveit. A szubkulturális közegben megalakuló zenekarok vagy a tiltott, vagy a tûrt kategóriába kerültek, ami jól érzékelteti a rendszer, különösképpen az államilag támogatott könnyúzenei rendszer által „alternatívoknak” tulajdonított veszélyt. A szcéna legfontosabb zenekarai, úgymint a Trabant, a Vágtázó halottkémek, az Albert Einstein Bizottság, a Kontroll csoport, a Neurotic és az Európa kiadó nyíltan vállalták ellenszenvüket a hivatalos zeneiparral szemben, melyet Csatári Bence és Jávorszky Béla bürokratikusnak, monopolisztikusnak, korruptnak és privilégiumokon nyugvónak jellemez (Csatári-Jávorszky 2016: 269-70.).
\end{abstract}

Jelen tanulmány az új érzékenység filmjeit a mozi és a könnyúzene egymás iránti tudatosságát elmélyítô, neoavantgárd esztétikai kísérletezésnek helyet adó, végsô soron pedig a képi és zenei alternatív önkifejezési formákat egyesítô alkotásoknak tekinti. A szokásosan ebbe a csoportba sorolt filmeken túl - vagyis Bódy Gábor A kutya éji dala (1983), Szirtes András A pronuma bolyok története (1983), Müller Péter Ex-kódex (1983), Wahorn András Jégkrémbalett (1984), Xantus János Eszkimó asszony fázik (1984) és a Rocktéritố (1988) címú alkotásai mellett - Tarr Béla Kárhozat (1987), Ács Miklós Sốn és Grósz (1988) és Monori Mész András Meteo (1990) címú filmjeire is kitekintést teszek, melyek amellett, hogy az underground zenekarokat, zenészeket és dalszövegeket a fentebbiekhez hasonlóan használják, az új érzékenység utóéletét is körvonalazzák. Bár nem teljesen homogén a felsorolt alkotások zenei orientációja, közös vonásuk, hogy nem helyezhetôek el nemzetközileg elterjedt múfaji keretekben, úgymint a zenés film, a musical vagy az életrajzi (dokumentum)film. A jellegzetesen magyar kontextushoz kapcsolódó filmekben a zene és a mozi kapcsolata nem esetleges, ugyanakkor nem redukálható periférikus elóadók népszerúsítésére, melynek keretében a mozi, mintegy átvéve a lemezstúdió és a rádióadó funkcióját, nehezen hozzáférhetô rétegzenei felvételeket rögzített és terjesztett. ${ }^{[1]} \mathrm{Az}$ új érzékenységet a hivatalos nyilvánosságtól megfosztott múvészi szféra és ellenkultúra politikai felhangokban gazdag önreprezentációs kísérleteként értelmezem. Jacques Rancière disszenzusfogalmát felhasználva a zene és a mozi szinergiáit olyan avantgárd stratégiáknak tekintem, melyek (1) a láthatóság késô Kádár-kori struktúráira reflektálnak, (2) az életvilágot uraló kiábrándultságot és a bizonyos elemeiben nihilista élményvilágot szólaltatják meg, (3) és a filmekbe illesztett koncertfelvételekkel és dalokkal a hivatalos zeneiparhoz képest a performativitás alternatív formáit dolgozzák ki. Jelen 
tanulmány nagyban támaszkodik a hetvenes-nyolcvanas évek marginális múvészetét vizsgáló kutatások célkitûzésére, ami K. Horváth Zsolt szavait idézve, „a múvészi cselekvést és eseményt részben, de nem egészében - ki szeretné vonni a tisztán esztétikai gondolkodás fennhatósága alól, s azt - a politikai és társadalmi szférát is magában foglaló - komplex kulturális kérdésként kezelné" (K. Horváth 2010: 124).

\section{Az új érzékenység mint kutatási probléma}

A 3T rendszere az államszocialista Magyarországon a társadalmi modernizáció Jürgen Habermas vizsgálta természetének szellemében összehangolt rendszerszintú mechanizmusként és a szolidaritás kommunikatív formáit erodálva uralta az életvilágot. Michel Foucault nyomán a normalizáló bürokratikus intézményeknek kiszolgáltatott állampolgárokról beszélhetünk, akiknek semmilyen vagy nagyon csekély hozzáférésük volt a demokrácia elengedhetetlen feltételét jelentô és az alulról jövô kezdeményezéseket felkaroló nyilvánossághoz. A kulturális élet „normalizációjáért” felelôs tiltás-tûrés-támogatás rendszere minden egyes szereplő esetében meghatározta, hogy számára a nyilvánosságot teljesen elérhetôvé, részlegesen elérhetôvé teszi, vagy abból kirekeszti. A korabeli múvészeti élet alternatív nyilvánosságát egy sor kutatás vizsgálta. Novotny Tihamér és Keserú Katalin a Vajda Lajos Stúdió, a periférikus képzőmúvészeti múhely történetét tárta fel, Szitha Tünde és Dalos Anna a neoavantgárd és kísérleti zenének otthont adó Új Zenei Stúdió fejlődését vizsgálta, Németh György monográfiát írt a vegyes politikai és irodalmi preferenciákkal bíró írók és költốk alapította József Attila Körrôl, Peternák Miklós és Gelencsér Gábor a dokumentumfilmesek és kísérleti filmesek menedékéül szolgáló Balázs Béla Stúdió történetét dolgozta fel önálló kötetekben, míg a nyolcvanas évek underground és újhullámos zenekarainak rendszerezett áttekintését Szốnyei Tamás, más vetületeit Klaniczay Gábor írta meg, ugyanerról a témáról és korszakról pedig Szemere Anna angolul publikált könyvet.

Ezek a gyakran nonkonformista és/vagy neoavantgárd csoportosulások a túrt vagy a tiltott kategóriákhoz tartoztak. A Balázs Béla Stúdió alkotómúhelyben is megforduló képzőmúvészekhez hasonlóan a budapesti underground zenei szcéna tagjait is rendszeresen megfigyelték, és más hatósági eszközöket is alkalmaztak, melyek célja nem más volt, mint „minél inkább leszúkíteni, lehetôség szerint egy - jól ellenôrizhetô - helyre koncentrálni ezeket a törekvéseket, hogy se idôben, se térben ne legyen módjuk az expanzióra" (Peternák 2014: 15). ${ }^{[2]}$ Ennek okai a gyakori ellenzéki nézetek hangoztatása mellett a marginális és alternatív kifejezésmódokban keresendô, a disszenzusban, amit Jacques Rancière a megszólalásért folyó harc természetes velejárójaként jellemez, és melynek célja megváltoztatni az érzékelhetô felosztásának logikáját. Az érzékelhetô felosztása „az a mód, ahogy a szimbolikus hierarchia absztrakt és önkényes formái az érzékelhetôségben megnyilvánulnak, ahogy a társadalmi célzatosságot az érzékelhetôség világai, a létezés, a kimondás és a látás elôzetesen kinyilvánítja" (Rancière 2011: 7). Az érzékelhetô felosztásának kirekesztố gyakorlata - Rancière gondolatmenetében - nem csupán azt határozza meg, hogy ki beszélhet, és ki nem, de a tér, az idô és a kommunikatív aktusok felett is felügyeletet 
gyakorol. A francia szerzô szerint „a politikai disszenzus nem az eltéró érdekeket és értékeket képviselô egyének vitában kibontakozó konfliktusát jelenti. A konfliktus valódi tétje az, hogy ki beszélhet, hogy mit kell a fájdalom hangjaként meghallanunk, és mit kell mondani ahhoz, hogy valami az igazságosság érveként hangozzon” (Rancière 2011: 2). Mindezek alapján az államszocialista kultúrpolitika és az alternatív kifejezésmódok közötti konfliktus nem esztétikai értékrendek különbségében keresendô, sokkal inkább az esztétikai érték eltérô felfogásában. A Kádár-kori rockzene politikai gazdaságtanát vizsgálva Szemere Anna fogalmaz úgy, hogy „amikor egy lemezkiadó vállalat elutasított egy szakadár vagy szokatlan stílust, döntésüket gazdasági, s nem politikai okokkal magyarázták: a(z elit vagy kisebbségi ízlés kielégítésére törekvô) rétegzenének nevezett alternatív hangzás eladhatóságát hangsúlyozták" (Saját ford. Szemere 2001: 12). Míg az érték(elési)-rendszer önkényessége fontos sarokköve volt a nyilvánosság felügyeletének, addig a disszenzus éppenséggel az eljárásokhoz kötött kompetenciák, engedélyek és jogosultságok, valamint az elfogadottá / el nem fogadottá nyilvánítás bürokratikus rendszerét kérdôjelezte meg. Röviden: az érzékelés és a megszólalás rendjének újrarajzolását, az addig kimondhatatlan kimondhatóvá tételét, az érzékelhetô újrafelosztását követelte.

A régió többi országához hasonlóan a láthatóságra törekvés az underground zenei szcénák alapvonását jelentette. A profi hangstúdiók, technikailag jól felszerelt koncerttermek, célzott marketingtevékenység és sajtótámogatás hiányában a zenekarok házistúdiókban kazettára rögzített felvételei jártak kézrôl kézre, míg alkalmi fellépéseiket egyetemista/fôiskolás rajongók és bohém értelmiségi barátok látogatták. Vályi Gábort idézve, „[a]z underground múvészek mintha valóban a föld alatt tevékenykedtek volna, be voltak zárva azokba a nehezen kihasított, s általában földrajzilag is marginális terekbe, ahol a koncertek zajlottak. Az általuk preferált és képviselt kulturális minták és üzenetek csak a szubkultúra kemény magjának személyes kapcsolathálóján szivárogtak tovább, barkácsmódszerekkel sokszorosított folyóiratok és kazetták segítségével” (Vályi 2003: 218). Az avantgárd képzômúvészekhez hasonlóan a zenészek is az érzékelhetố felosztásának rendszerében a hierarchia alsó régióiban kaptak helyet, ahol a bürokratikus szabályozások, az engedélyek elutasítása, a betiltott kiállítások és koncertek, a rendőrségi zaklatások és az ellenszenves médiareprezentáció a marginalitás közös tapasztalatában erôsítette a két csoport kapcsolatát, együttmúködési igényét. Klaniczay Gábor értelmezésében a múvészeti avantgárd és szubkultúrák egymás iránti tudatosságát történelmi tényezốk is erôsítették: „Amikor a '60-as évek avantgárd formai kísérletei kezdtek ezoterikussá lenni és elszigetelődni, egyes alkotók úgy próbáltak szert tenni nagyobb közönségre, hogy átvették az ifjúsági szubkultúra bizonyos formai jegyeit. Másfelól pedig ez az ifjúsági szubkultúra intellektuális kidolgozottság és esztétikai megoldások tekintetében kezdett egyre jobban hasonlítani az avantgárd múvészeti produkciókhoz" (Szilágyi 1985a: 20). Ezek a csoportosulások a kultúra és a társadalom rendjében idegen mentalitásként ékelődtek be, és a nyilvánosság újraelosztása mellett a disszenzust és a hierarchiák bomlasztását a múvészet, a politikailag tudatos állampolgári attitúdök és a demokratikus életvilág alapfeltételének tekintették. A magyar helyzet specifikumát a késő Kádárkor skizofrén társadalmi dinamikája és az emberek politikai aktivitástól való elfordulása jelentette, ami egyfelól erôsítette a szubkultúrák kialakulását, másfelól megnehezítette azok - demokratikus 
államokban tapasztalt - megerôsödését. ${ }^{\left[{ }^{[3]}\right.}$ A magyarországi ifjúsági szubkultúrák közül a budapesti underground esetében fonódott a leglátványosabb módon össze a múvészi és politikai disszenzus, és alakult ki egy olyan világmeghatározás, mely a szélesebb társadalmi valóság szimbolikus tartópilléreinek elutasításakor polgárlétre támaszkodott. Rácz József megfogalmazásában „a hazai underground szubkultúra [...] nem polgárellenes volt, hanem éppen polgári eszmények - és még inkább életstílusok, életérzések - megőrzését, átmentését célozta (olyan eszközökkel, amilyenek rendelkezésre álltak)" (Rácz 1998: 64).

Ezek a polgári eszmények a nyárspolgári attitúdöktól éppúgy mentesek voltak, mint a kispolgári racionalitástól, és alapvetően a rock and roll radikális, ugyanakkor játékos élményvilága felól építkeztek, és az eszmények/értékrend helyett a múvészi eszközökkel és gyakorlatokban formálható és kifejezhetô polgári identitást helyezték elôtérbe. Klaniczay fentebb idézett gondolatát a pop regisztere felé nyitott avantgárd szemléletmódról K. Horváth (K. Horváth 2010) és Najmányi László (Najmányi 2010) is megerôsíti, mégpedig a Spions zenekar és Molnár Gergely akciómúvészete kapcsán.

Egyértelmú, hogy Molnár nem eszményekben, hanem egy személytelen és formalista intellektuális ágenciában gondolkodott, a polgári identitás öndekonstruktív, a tér és látvány médiumait használó akcióiban. Ez olvasható ki múvészi pozíciójának kiáltványszerú leírásából:

A Spions olyan múvészekből áll, akik a rock and roll-t nem kedvtelésból csinálják, hanem kényszerbôl. Nem show-business számukra, hanem kiképzés. A Spions nem sztárokból áll, hanem katonákból. Nem látványosságban utaznak, hanem cselekvésben. Nem individualisták, hanem aktuálisak. Nem a rock and roll a médiumuk, hanem ôk a rock and roll médiumai. Készen állnak egy olyan üzenet közvetítésére, amelyet gyúlölnek. A divat fontosabb számukra az etikánál. Kizárólag a rock and roll törvényeit veszik figyelembe; ezek a törvények kizárólag formaiak. Ezek a törvények, mint minden esztétikai kód, a vízió törvényei. [...] Olyan médiumok, akik pontosan tisztában vannak a helyzetükkel. Az utasítást, melyet követnek, értik is. Gépek tehát, nem pedig emberek. Ily módon nem múveket alkotnak. Amit létrehoznak, velük együtt pusztul. (idézi Szônyei 337) ${ }^{[4]}$

Ez az összetett és ellentmondásoktól sem mentes fogalmazvány a rock and roll-t olyan performatív aktusnak tekinti, amely hangok, fények, gesztusok, szövegek előre megszerkesztett folyamába helyezi mind az alkotót (elôadót), mind a közönséget. Az elôadás és az abban részt vevô szubjektumok viszonya alá/felérendelő; az egyéniség és individualitás leértékelődik, míg az intellektualitás és a szabálykövetés felértékelôdik a performansz során, melynek múvészi legitimitást az intenzitás és a megismételhetetlenség kölcsönöz. A rock and roll üzenete: kiképzés és pusztulás, egy önfelszámoló gesztus gépies beteljesítése. Ez az üzenet egyszerre tartalmazza a punk jó ízlést és szentimentalizmust tagadó, radikalizmusát sokk-taktikákkal gyakorló attitúdjét, és szólaltat meg sajátosan magyar/kelet-európai felhangokat: az öngyúlöletet és a pusztulásra ítéltséget. A demokratikus kultúrába integrálhatatlan, indoktrinációt magasztaló eszmények Molnár általi dicsőítését K. Horváth politikai gesztusnak tekinti: „a diktatúra jelenlétében nyíltan 
magasztalni mindezt, vagy egy besúgókkal átitatott légkörben a kémek - lényegükböl, létmódjukból fakadó - etikátlanságát dicsôíteni durva retorikai rájátszás volt egy politikai evidenciára” (Kiem. az eredetiben, K. Horváth 2010: 134). Az üzenet tehát egyszerre univerzális és lokális. A punk egyetemes üzenete a zenei és identitásbeli korlátok és skatulyák folyamatos meghaladására, szórakozás- és profitközpontú elôadások helyett egy dühös-távolságtartó attitûd militarista színpadra vitelére szólít fel. A lokális (art punk) üzenet az ember (elôadó) és a rendszer (zeneipar) viszonyában ismerteti fel az alávetettséget és ezt a szervilis mentalitást a végletekig fokozva, belülrôl rombolja le: a performansz múlékonyságában megélhetôvé teszi a kiszolgáltatottság állapotának pusztulását. Az üzenet olyan akció, amely ösztönösen kapcsolja össze az esztétikait és politikait, a kapocs pedig maga a disszenzus mint eredendô meg nem alkuvás a kádári „aki nincs ellenünk, az velünk van” szellemiségével, amely a korabeli hivatalos múvészet és populáris kultúra mellett a társadalmi szférára is rányomta a bélyegét.

Az új érzékenység mozija több ponton kapcsolódik a fentebbiekhez, leginkább abban, ahogy üzenetközvetítóként, médiumként tekint magára: a domináns kultúrába integrálódni nem akaró rock and roll múvészetrôl és underground szcénáról ad hírt. Arról a „polgári” identitásról üzen/számol be/tudósít, melynek a kirekesztettség jutott osztályrészül, és amely az aktivizmustól az akcionizmus felé fordul, ugyanakkor a privát szférába való visszavonulásban és az elidegenedés személyes tapasztalatában társadalmi kortünetet mutat fel. A szóban forgó filmek az érzékelhetô hierarchikus felosztottságának a kordokumentumai, ugyanakkor az alá/felérendelô viszonyt esztétikailag bomlasztják, mégpedig a szeriális szerkesztés és permutációs elbeszéló logika, a barkácsolástechnikák, improvizatív eljárások és dekomponált plánok használatával, valamint a közérthetôség elvének megkérdôjelezésével (Pápai 2009: 147). Az új érzékenység játékfilmes irányzatáról írt kulcsfontosságú tanulmányában Pápai Zsolt ezeket mellérendelô kapcsolatoknak nevezi, melyek a filmek transzgressziós, Gesamkunstwerk jellegével és az önként vállalt dilettantizmussal kiegészülve az akadémikus stílus nyílt kritikáját fogalmazták meg. Pápai szavaival „[a] profizmus tagadása a szeriális elvet érvényesító építkezésben, az elemek közötti rangsorolást hanyagoló közelítésmódban, azaz a mellérendelés poétikáján látszott legerôteljesebben az új érzékenységben" (149).

A hangosfilmekre jellemzó mediális hierarchia, vagyis a zene mozgóképnek történô alárendeltsége ugyancsak megbomlott. A filmekben megszólaló dalokból hiányzott a filmzene hagyományos, a jelenetek dramaturgiai fokozását szolgáló funkciója, de éppúgy hiányoztak a zenére komponált montázsszekvenciák, az érzelmi atmoszférateremtést, a karakterábrázolást vagy a képi motívumok értelmezését szolgáló zenei betétek. A zene hallhatóvá és autonómmá vált, egy képekkel nehezen kifejezhetô érzékenység és tapasztalat médiumává. Hasonlóan atipikus volt a zenészek filmes jelenléte, ami - a szokásostól eltérôen - nem tekinthetô sem közönségvonzó vendégalakításoknak, sem sztárimázsépítésnek. A zenészek szubkulturális identitások és életmódok autentikus megtestesítóiként, az értelmiségi fiatalokra jellemző kiábrándultság és irányvesztettség médiumaiként jelentek meg. Az underground figurák történetekbe emelésének 
okait is megvilágítja Bódy Gábor válasza arra a kérdésre, hogy miért osztotta magára a Kutya éji dala fôszerepét: „Úgy éreztem, hogy én saját úgynevezett múvészi tévelygéseim, önigazolási törekvéseim talaján állva mélyebben ki tudom bontani ezt a figurát, mint egy színész, aki biztosabb a feladatában, az utánzásban, s akit esetleg elcsábítanak a szerep külsôségei” (idézi Kovács 1983: 13).

\section{Az új érzékenység forrása, filozófiája és a rockzene ágenciája}

A filmes új érzékenység újdonsága a létezô szocializmus mélyen beágyazott viszonyait - a világ belsô ellentmondásait, lakóinak érték- és identitásválságát - felfedni képes ágenciához kötődik. Ujjonságról beszélek, holott Jeles András A kis Valentinója (1979) már egyértelmúen ebbe az irányba tapogatózott, amikor felmondta a múvész és a paternalista hatalom között fennálló hazug egyezséget. Ebben a gesztusban Gelencsér Gábor a hetvenes évek paraboláival való szakítást ismeri fel, szakítást azzal a beszédmóddal, amely az atyáskodó hatalom és annak lekezelô képviselôivel szembeni egyéni és közösségi frusztrációkat a nyílt kritikát mellózve juttatta érvényre, így az elégedetlenséget úgy fejezte ki, hogy hallgatólagosan elfogadta a rendszer múvész felett gyakorolt hatalmát. Hovatovább nemcsak elfogadta, de legitimálta is az érzékelhetô elosztásának aktuális formáit, indirekt módon tehát hozzájárult a konszenzushoz, ami hierarchiákat felállítva szabályozta, hogy ki, mirôl és hogyan beszélhet. Gelencsér szerint Jeles célja A kis Valentinóban „megsejtetni valamit a konkrét társadalmi-történeti meghatározottságába belegabalyodott emberi lét nagyságából, méghozzá úgy, hogy ehhez ne kelljen - szükségszerúen - ideologikus modellé, allegóriává, szimbólummá, metaforává stilizálni a bemutatott világot, illetve történetet" (Gelencsér 2002: 408). A disszenzus a tiltakozásnál radikálisabb múvészi ágenciát jelent, a hamis társadalmi béke elutasítását nem egy eszményített értékrendre hivatkozva, „nem a szabadsághiány analitikuskérdező-oknyomozó attitúdjével teszi, hanem a helyzet puszta rögzítésével: ez van" (Kiem. az eredetiben, Gelencsér 2002: 396). Amikor Jeles lemond az ellenállás puha formájáról, valójában arról mond le, hogy az utópikus jövô nézôpontjából olvassa a jelent: a „tét nélküli ideologizálásról” mond le (Gelencsér 2002: 281). Ehelyett a szocializmus társadalmi-ideológiai projektjének a kudarcát tényként kezeli, az életvilágot pedig labilisként, tervezhetetlenként és kiüresedettként ábrázolja. Gelencsér megfogalmazásában Jeles „nem »megírni«, sokkal inkább »kiolvasni“ igyekszik a "mindennapi élet fantasztikumát«; számára látvány és sors megjelenése a vásznon nem cél, hanem forrás, amelyből nem összeáll, sokkal inkább lefoszlik a jelentés" (408-9.).

A kis Valentinóban ábrázolt stagnáló világot mutatják be az új érzékenység filmjei is, ugyanakkor a mindenre kiterjedô hiányérzetet, kilátástalanságot és a létezố szocializmus nihilizmusát nem a társadalmi valóság közegében, hanem az underground zenei regiszterével ragadják meg: az egyén és a világ feszültségének zenei-színpadi eszközökkel való megszólaltathatósága és előadhatósága válik fontossá. ${ }^{[5]}$ A siralmas állapotokat nem megmagyarázni szeretnék, hanem a rock and roll nyelvén kifejezni. Molnár Gergely kiáltványának szellemében azt mondhatjuk, hogy az üzenetük csupán annyi, hogy minden (kép, hang, test, tér stb.) közvetítô: médium. Bár kissé más 
kontextusban, de ezt hangsúlyozza Szilágyi Ákos is: „[k]özös, hogy személyes és múvészi erôfeszítéseik arra összpontosulnak, ami levezethetetlen a személyben, ami elvehetetlen tôle. Az új érzékenység az - ami: leírható és értelmezhetô, de nem lehet ideológiát csinálni belóle. Vagyis: a közösség alapja itt az, hogy nincs közösség és közösködés senkivel és semmivel. Az ideológia: az ideológianélküliség, ideológián túliság” (Kiem. tôlem. Szilágyi 1985a: 27). [6]

Az ideológiai keretek elutasítása a zenei underground alapvonása volt. A rendszer legitimitásválságával párhuzamosan szembetûnô volt az ifjúsági kultúra terjedése és olyan rock and roll zenekarok szubkulturális népszerûsége, melyek az „ez van” életérzés megosztását fontosabbnak tartották a fanatikus heroizmusnál. Az elvehetetlen, elidegeníthetetlen életérzés természetes részét maga a zene jelentette, így nem meglepó, hogy több korabeli dalnak a rock and roll regiszter volt a közvetlen tárgya, úgymint az Európa kiadó Fiatal magyarok (1997) címú dalának: „Fiatal magyarok rázzák az utcát / Budapest remeg és maguk se tudják / hogy ezt a rezgést melyikük hozta / a külvárosból a belvárosba”. Ezzel cseng össze a Neurotic $A$ Rock'n'roll az... (1988) címú Pajor-szerzeménye, ahol a zene ugyancsak életfontosságú, önteremtő és nehezen definiálható, ugyanakkor az identitás lényegéból fakadó (a devianciától, nonkonformizmustól sem mentes) városi erôként jelenik meg: „Mikor a nap lemegy én felkelek / felcsörgetem a partnerem / és azt üvöltöm az utcán / hogy a rock'n'roll az nem egy tánc”. A Kontroll csoport $A$ rock'n'roll egy állat (1993) címú száma a hatalom számára veszélyes, kontrollálhatatlan zenérôl, a rock hierarchiákba beépíthetô, de azokat felforgatni is képes erejérôl beszél:

A rock'n'roll egy állat

veszélyesebb nálad

a tenyeredből eteted ôt

\author{
A rock'n'roll egy ember \\ nem tarthatod szemmel \\ nincsen annyi szabadidőd
}

A rock'n'rollból élsz

A rock'n'rolltól félsz

A hagyományos motivációs struktúrák visszaszorulásával párhuzamosan az ifjúsági szubkultúrák a társadalmi és egzisztenciális bizonytalanság kitüntetett helyeivé váltak. Rácz József „a többségi kultúra és szubkultúra szimbolikus univerzumai közötti, az elóbbiból az utóbbi felé irányuló mozgásnak két formáját - a kirekesztettséget és a kivonulást - különbözteti meg (Rácz 1998: 52). A 
nyolcvanas évek underground zenei szcénájához kötôdő szubkulturális formációit a kivonulás, a hivatalossal össze nem egyeztethetô valóságmeghatározás, a disszenzus jellemezte, ami a diktatúra természetébôl adódóan a láthatóság rendszeréból való kirekesztettséggel járt. A csoport valóságmeghatározásában a bizonytalanság aktív szerepet játszott, mégsem a külsô tényezők összhatására létrejövô siralmas állapotot jelölt. A bizonytalanságot nem elszenvedni és túlélni, hanem kiprovokálni és megélni kellett. Az identitás elbizonytalanítása és lecsupaszítása az identitás újraformálásának, valamint az elidegeníthetetlenül emberi én-elemek megtapasztalásának az eszköze volt, éppen ezért nem jellemezhetô nihilizmusként. Az elbizonytalanodás, az értékválság és a lecsupaszodás folyamatában rajzolódott ki az egyén magidentitása és alakultak ki a múvészi önkifejezést megalapozó személyiségjegyek. A nihilizmus helyetti énkeresést hangsúlyozza Szilágyi Ákos is: „Az új érzékenység exhibicionizmusa helyett talán - Pilinszky János kifejezését idézve - a múvészet »új meztelenségi fokáról« kellene beszélni. Ne feledjük, hogy ez az »én« nem szellem, nem tudat, hanem a tovább már nem bontható egzisztencia. Ezért vonzódik az elementárishoz, a vadhoz, az ösztönöshez, a primitívhez, a mármár állatihoz. Csak külsô látszatokon túlhaladva érzékelhetjük ezt az »én«-állapotot” (Szilágyi 1985a: 29). Az énkeresés alapjául szolgáló elidegeníthetetlenül emberi impulzusok sokszínúségéból - a Vágtázó halottkémek tagjainak tobzódásából egy ösztönös-archaikus énvilágban, a Bizottság zenészei számára fontos játékos-hedonista diszpozíciókból, Pajor Tamás animális-hedonista személyiségjegyeiből, valamit Méhes Marietta naiv-érzéki és Víg Mihály ösztönös-bensőséges énállapotaiból - fejlődnek ki a magyar underground rockzene egyedi „nyelvjárásai”.

Bódy Gábor pontosan érzékeli, hogy az underground zenekarok és zenészek világmeghatározása és énkeresése nem nihilizmusban gyökerezik. Nem véletlenül osztja $A$ kutya éji dala egyik szerepét Grandpierre Attilára, aki a VHK egyik első koncertjét a következő szavakkal vezette fel: „Mi nem szórakozunk! Nehogy azt higgyétek, hogy itt szórakozni fogtok. Aki szórakozni akar, túnjön haza. Otthon szórakozzon, a tévé elôtt! Itt valami egészen mást fogtok kapni!" (Seszták 1988: 88) A punk elôre kitervelt sokk-taktikáján túl ezek a szavak a koncertterem közösségi világteremtés céljából történő elfoglalását konstatálják. A közösségi világteremtés Grandpierre felfogásában szorosan kapcsolódik a népzenéhez, ami olyan szertartásos és mágikus zene, amely „letisztult állapotban, belsô szükségszerúségbool születô, minden sablontól mentes [...] öntörvényú, saját belsô tartalmát a legkövetkezetesebben és a legteljesebben ragadja meg, és elemi erejú, az »én« teljes hatóerejével születik" (Seszták 1988: 88). A VHK spontán születô, a természeti erôk nyersességét a természeti népek mágikus valóságértelmezésével vegyítô zenéjének társadalmi elkötelezettsége - vagyis, hogy visszajuttassa „a nép önkifejezési formáit a néphez” (Seszták 1988: 89) - az aktuális kultúrpolitikának és a népi demokrácia hivatalos valóságképének félreérthetetlen kritikája volt. 


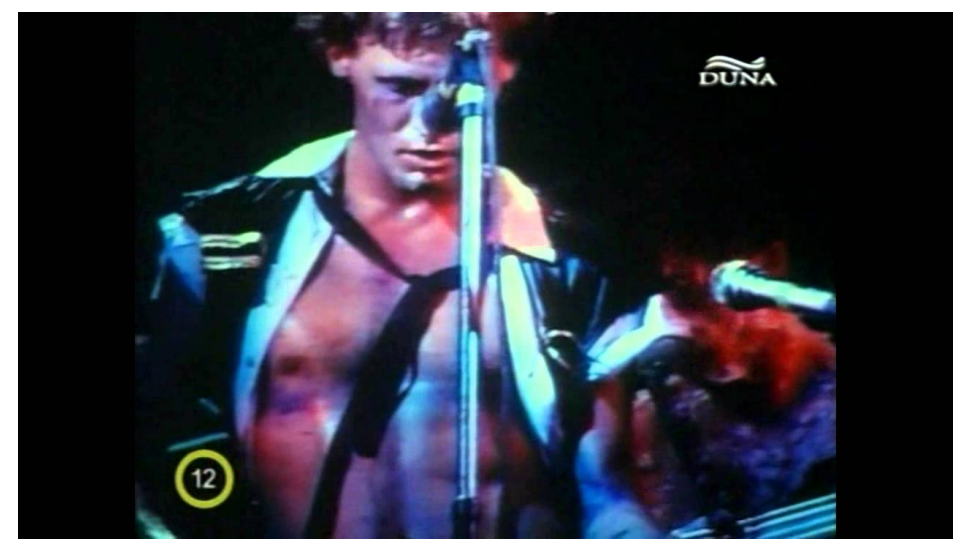

A kutya éji dala (Bódy Gábor, 1983)

Ezzel összhangban A kutya éji dalát „népfilmnek” tekinthetjük, mely tudatosan zárkózik el a korabeli valóság ideologikus ábrázolásától, és a VHK spontán energiákban születố zenéjéhez hasonlóan a kortársak hangját vagy inkább frusztrációkkal teli üvöltését autentikusabbnak tekinti a pártideológiai szólamoknál. Jeleshez hasonlóan Bódy is a céltalanság és irányvesztettség állapotrajzát kínálva konstatálja az államszocialista rendszer (mint társadalomjobbító ideológiai kísérlet) kudarcát, és egy nyíltan disszenzuális pozíciót vesz fel. Jósvai Péter szavaival „A kutya éji dala teljesen olyan, mint az Ifivezetốk - megint teljes hülyét csinált mindenkiből a rezsim oldalán. Azt hihették, hogy kaptak maguknak egy új mai magyar filmet, de helyette egy hatalmas tablót kaptak, egy gigantikus tanulmányt arról, hogy mennyire rossz és halott a magyar életvalóság”. A film teátrális pózai, alig hallható párbeszédei, felnagyított Super 8-as és videóra rögzített képei az amatôr film felé tett tisztelgésen túl a koherens történetmesélés lehetetlenségét példázzák a társadalmi konszenzus széthullásának világában. Bódy koncepciózus módon vonzódik a raszteres és zajos képhez, mintha a filmes akadémizmus makulátlan beállításai már mindig is látszatvalóságot ábrázolnának, vágyképek lennének. A kutya éji dalában a filmmúvészet konszenzuális képformájával éppenséggel az underground zenekarok koncertfelvételei állnak szemben: ezek az alacsony felbontású képkockák képesek kifejezni az emberi viszonyokat uraló apátiát és megmutatni a zenében kibontakozó énkeresést, legáltalánosabb szinten pedig a késő Kádár-kor tárgyi kultúráját és mentalitásformáit. Paradox módon az alacsony felbontás nagy felbontássá válik, amennyiben „a nagy felbontás azt jelenti, hogy 30 évvel késôbb, ha megnézed a filmet, benne lesznek a részletek a valóságból: autók, bútorok, ruhák, divat, ahogyan pénzt kerestek, ahogyan beszéltek, ahogyan szeretkeztek, ahogyan az autókra és fegyverekre gondoltak. A nagy felbontás egy kultúr-antropológiai aspektus" (Jósvai).

\section{A disszenzus színpadra vitele}

Az új érzékenység filmjeiben szereplô zenekarok színpadhasználatát, a fentebbiekhez kapcsolódva a „low-fi” jelzôvel illethetjük, ami a komoly hiányosságokat mutató infrastruktúra mellett a sztárok látványosságteremtố elôadóstílusát, illetve a hagyományos koncertekre jellemzô szórakoztató elemeket is nélkülözte. Klaniczay Gábor korabeli beszámolója Víg Mihály színpadi 
személyiségérôl érzékletes képet kínál minderrôl:

Emlékszem, állandó baj volt a szereléssel, elment a mikrofon, elszakadt az egyik gitár húrja, több számot újra kellett kezdeni [...] Ebben a zúrzavarban Víg Mihály mégis ura maradt a helyzetnek. Mintha lett volna valami szándékosság, ôszinteség abban, ahogy a bukdácsoló elôadást, az amatôr színvonalon megmaradó zenélést kíméletlen rendezetlenségében szabadította rá a közönségre. A sokszor megbicsakló elōadás romhalmaza, törmeléke alól kandikált ki, súlyos sebekből vérzett és talán ettôl vált hitelessé ez a hajdani tinédzser-idillekrôl, ábrándozásokról szóló líra. (Klaniczay 2003: 377)

Eltünt a színpadi tér nagykoncertekre jellemzô kitüntetett és megbecsült jellege, de ugyanúgy hiányzott a közönség és az elöadó fizikai elválasztottságát verbális kontaktussal és heves gesztikulációval kiegyensúlyozó dramaturgia is. ${ }^{[7]}$ A hivatásos zenészek és hivatalos közegek együttes irányítása alatt álló szórakoztatóipar az érzékelhetô kirekesztô felosztottságát és a torz nyilvánosságot jelképezte a szubkultúrák számára, melyeknek nyíltan vállalt amatôrizmusa erkölcsi fölényt sugallt, és a csak a kulturális periférián megteremthetô autentikusság élményét kínálta.

Egyetértek Pápaival, aki szerint az új érzékenység filmjeiben „az underground zenekarok nem csupán az ábrázolás médiumai, hanem annak tárgyai lettek, mégpedig jelentékeny részben a nyilvánosságban elfoglalt pozíciójuknál fogva [...]. [A]z alternatívok szerepeltetése tehát automatikusan vonta magával a nyilvánosság problematikus felvetését" (Pápai 2014: 150-1.). Pápai érzékenyen elemzi a hierarchikus és ellentétes valóságmeghatározásokon alapuló nyilvánosságok filmes jelenlétét. Szirtes András A pronuma bolyok történetének egyik jelenetében szereplô alak felforgató-disszenzuális gesztusait olyan, a filmmédiumra vonatkozó önreflexív megnyilvánulásként vizsgálja, ami a színpadhasználat általam vizsgált transzgresszív politikáját idézi. A szóban forgó jelenetben az egyik szereplô a filmmúvészetet komolyan vevő rendezôket hülyékként aposztrofálja, reményét fejezi ki, hogy a közönség soraiban is sok hülye ül, illetve, hogy egyszer minden néző meghülyül, saját mondandóját hülyeségnek nevezi, majd Grandpierre Attila fentebb idézett provokatív stílusában üzen a közönségnek: „Talán jobb lenne, ha már most kimennél a moziból. Addig én várok. Van időm. Ráérek...”. A közérthetőség és jóizlés határait feszegetô monológ imitált infantilizmusa mögött a korabeli viszonyok pontos látlelete olvasható ki, amit Szemere Anna „a »legitim«, a hivatalos és tiszteletreméltó múvészet, valamint az elutasított, tiltott és üldözött múvészet" konfliktusaként jellemez (Szemere 2001: 51). Paternalizmus és nonkonformizmus - vagyis az akadémikus formát preferáló, pozíciójukat féltô szerzôi filmesek és a kísérletezô szemléletû rendezốk - egyenlốtlen harcában a hülyéskedés hasonló szerepet tölt be, mint a Víg Mihály koncertfellépései kapcsán megidézett amatôrizmus: éppen azért hat az autenticitás erejével, mert nem tartja tiszteletben a hamis játékszabályokat, a hatalom által legitimált és a hatalmat legitimáló múvészet komolyságát, profizmusát. Az infantilizmus és a mimikri hasonló esetére hívja fel Pápai a figyelmet a Jégkrémbalett kapcsán, különös tekintettel a Békásmegyer címú dal szövegére, mely egyszerre idézi meg és figurázza ki a 
mozgalmi dalok komolyságát:

Kelj fel, kelj fel, vár a munka, vár a gyár

Kelj fel, kelj fel, vár a hivatal, vár a vár

Az ágyból gyorsan kikelek

A mosdóba kiszédelegek

Borotválkozok és fogat mosok

Addig se nagyon gondolkodok

Mert tipikus mai munkaerô vagyok

A békásmegyeri rabszolgatelepen lakok

A munkásmozgalmiságot dicsôítô beszédmód komolyságát a végigbulizott hétvégét követô reggel kapkodásának a leírása ellenpontozza. A másnaposan induló hétköznapon a felkelés komoly fizikai és lelki kihívást jelent: a szóhasználat teljességében mentes a forradalmi és magasztos konnotációktól. Az idealizált munkáskép helyett a jelenet táskás szemú, kissé illuminált emberhordát mutat, akik alig férnek el a szúk terekben. Hasonlóképpen, a békásmegyeri panellakás, mely a hivatalos diskurzusban a szocialista jóléti állam jelképe, az ott lakók számára rabságuk szimbólumaként jelenik meg. Az államszocialista nyilvánosság legitimálta idealizált Békásmegyer-képpel össze nem egyeztethetô ábrázolás természetesen felkeltette a cenzorok figyelmét, és a filmet csak alkalmi vetítéseken láthatták a nézők, a hanganyag pedig legfeljebb a kalózmásolatoknak köszönhetôen tudott elterjedni.

A láthatóság és hallhatóság feletti adminisztratív kontroll, mely eredetileg és elsôsorban a politikailag kifogásolható tartalmak kiszûrésére irányult, az új érzékenység filmjeiben az élet minden területén jelenlévő felügyeletként kerül ábrázolásra. Ezzel párhuzamosan, minden olyan szubkulturális és múvészi megnyilatkozás a disszenzus jelentését hordozza (vagyis politikai), ami a nyilvánosság szerkezetének hierarchikus viszonyaira reflektál, akár mert kifordítja, akár mert dokumentálja azokat. Az elsóre kínál példát a Jégkrémbalett egyik jelenete, amelyben az 1982-es labdarúgó-világbajnokság döntôjének közvetítését feLugossy László, mint tele-sámán szakítja meg. A szocialista televízió közszolgálati jellegét problematizálja a Bizottság frontemberének A szerelem a világon mindenütt egyforma, csak nálunk egy kicsit más címú kiselôadása, az ismeretterjesztô-népmúvelô músorforma szubverzív imitációja (mimikrije). feLugossy nem kizárólag - a szerelem ihlette dadaista meditációt aktképekkel vegyítô - gerillaadásával provokál, hanem inkább azzal, hogy a televíziós népnevelés iránti társadalmi érdektelenségre, a közszolgálatiság magasztos eszményének elértéktelenedettségére mutat rá. Értelmezésemben az egyértelmú nemtetszésüket kinyilvánító focirajongók a szellemi gyarapodással szemben a 
szórakozáshoz való joguknak adnak hangot. A jelenet a közmédia korabeli viszonyairól kínál pontos diagnózist, a politikai irányítás alatt álló nyilvánosságról, ami a hatalom legitimációs válságának köszönhetôen maga is megalkuvásokra kényszerül. Szembetúnô a párhuzam aközött, hogy a televízió egyre inkább apolitikus, a puszta szórakoztatást szolgáló tartalommal képes legitimitásra szert tenni, míg a hatalom a populáris kultúra óvatos szponzorálásával tudja elfedni legitimitásválságát. A gyengülô társadalmi támogatottsággal szembesülố rezsim az egyre inkább depolitizálttá váló nyilvánosság felügyeletével hatalmát, pontosabban látszathatalmát fitogtatta. Ugyanakkor a nyilvánosság politikai felügyeletének leértékelődésével párhuzamosan egyre inkább felértékelôdött a társadalmi kontroll, az egyetértés arról, hogy a jó ízlés és a közerkölcs védelemre szorul. A kutya éji dalában a média nem televíziós adás, hanem egy televíziós stáb formájában jelenik meg, akik a VHK tagjaival szeretnének beszélgetni. Az intézményes és szubkulturális identitások szembenállását a ruhaviselet, a testtartás és kameratudatosság mellett a riporter közhelyes kérdései és az interjúalanyok irreleváns válaszai érzékeltetik. A kérdezô és a válaszadók elbeszélnek egymás mellett, a konszenzushiány teljes a tekintetben, hogy melyek az aktuális problémák, hogy mirôl érdemes beszélni, és mirôl nem. A közös nyelv egyetlen pillanatra jön létre, de akkor is a nyilvánosság kapuinak bezárultához vezet. „Nem azért születtél, hogy mászkálj az utcán, mint egy kis pók, bazd meg" -, mondja a zenekar egyik tagja a mikrofonba, mire a megilletôdött riporter az operatôrre néz, majd kijelenti: „Nem, ezt nem vehetjük föl.” A szitokszó talán öntudatlan, talán szándékolt használata azonnal aktiválja a média kontroll-szerepét (közerkölcsvédô szerepét), ugyanakkor azt is félreérthetetlenné teszi, hogy a disszenzus nyelve egyedül azt akarja kimondani, hogy nincs közös nyelv.

Az új érzékenység filmjeiben számos - a nyilvánosság természetrajzát felvázoló - mediális gerillaakciót és nyelvi provokációt találunk, ugyanakkor a nyilvánosság és védôkorlátai a fizikai terek viszonyában is megjelennek. A Rocktéritố egyik jelenetében Pajor Tamás a Fiatal Mûvészek Klubja kapujában arról vitatkozik az egyik bennfentessel, hogy van-e joga belépni a szórakozóhelyre. Pajor érveiben - „fiatal múvész vagyok” - és az intézményt felügyelô személy ellenérveiben, miszerint az általában részeg Pajor több ízben inzultálta a vendégeket és megsértette a jóízlés határait, a nyilvánosság két kibékíthetetlennek tûnô felfogása feszül egymásnak. Jelen esetben a disszenzus a terek feletti kontrollt megalapozó tudások és szabályok legitimitását kérdójelezi meg, azt, ami alapján eldól, hogy ki lehet bent is, és ki lehet csak kint. Az Ex-kódexben szereplő Hashshashin szekta térhasználata ezeket a szabályokat hágja át, többek között abban a jelenetben, amikor a csoport (a budapesti zenei underground számos tagjával a sorai között) megjelenik egy témába vágó egyetemi elóadáson. Beszédes adalék, hogy a szektatagokon kívül szinte senki nincs az elôadáson, így kisajátíthatják, illetve sajátos szubkultúrájuk köré szervezhetik a nyilvános teret.

\section{Színpadra vitt identitásválság}

Az underground zene disszenzuális volta abban is megnyilvánult, ahogy az identitásválságot 
színpadra vitte. Az alábbiakban Xantus, Bódy és Wahorn rendezéseiben vizsgálom meg az előadók válsághoz és identitáskereséshez fưzôdoo egyedi viszonyát. Az Eszkimó asszony fázik fôszereplôje (Méhes Marietta) egy életével elégedetlen fiatal feleség, aki beleszeret a nemzetközileg elismert zongoristába, majd maga is belekóstol a zenei karrierbe. Elsô fellépésén egy munkásfiatalokból álló férfiközönség elôtt lép fel. Méhes félrészeg, fejüket rázva ordítozó és vadul táncoló csövesek és rockerek elôtt rock-blues dalt énekel. Ruházatuk, viselkedésük és maga a zene pontos képet fest a rajongók élményvilágáról: míg a bốrszerkók a robbanékony férfiasságot hangsúlyozzák az énekesnô szexi, testre simuló ruhája és erős sminkje a nôiességet, mint látványosságot helyezi elôtérbe.

A film késôbbi jeleneteiben az explicit szexuális öltözködés eltûnik, a zene kifinomultabbá, szövegcentrikussá válik, a közönség pedig visszafogottabbá. Két különbözô szubkultúrát látunk, a koncertek hangulata a fiatalok társadalmi helyzetét is olvashatóvá teszi. Szemere Anna nyomán az egyiket a keményrockot preferáló nyájmentalitással és hipermaszkulin értékrenddel bíró, valamint a munkásközösségekre jellemzô hôsiességkultuszt követố csövesek szubkultúrájaként, míg a másikat a középosztálybeli marginalizált fiatalok körében népszerú, a paternalista, antidemokratikus intézmények és viszonyok ellen lázadó avant-rock szubkultúraként írhatjuk le (Szemere 2001: 40-42.). Ez a különbség a koncert közösségi élményét strukturáló dinamikában is megmutatkozott: a csövesek a vad bulizást és a hagyományos szórakozást szolgáló színpadi produkcióra vágytak, míg a bohém-értelmiségi közönség tagjai visszahúzódó megfigyelôként, ugyanakkor feszélyezettség nélkül vettek részt a koncerteken, hasonlóan a zenészekhez, akik próbateremszerú, intim térnek tekintették a színpadot. Tünetértékú, hogy a fellépéseknek otthont adó termek többségében nem volt színpad, esetleg csak egy alacsony pódium, ami testközeli kapcsolatot tett lehetôvé nézô és előadó között. Ezért is tud az Eszkimó asszony fázik-ban Méhes olyan könnyedséggel odasétálni a közönség soraiban álló férjéhez, mintha csak a szobából menne ki a konyhába. Mindezt egy szám közben (a dal instrumentális része alatt) teszi, ami a színpad térbeli nyitottsága mellett az élô zene formális (dramaturgiai) kereteinek a felbomlását is érzékelteti. ${ }^{[8]} \mathrm{Az}$ underground zenekarok színpadhasználata kapcsán hasonló megfigyeléseket tesz Rácz és Zétényi is: „Mindez a változékonyságot és mellérendelést fejezte ki: az énekesek és a többi zenész, a zenészek és a közönség viszonyában, szemben a hierarchizáló keményrockkal és más popmúfajokkal" (Rácz - Zétényi 1998: 43). Az itt megfogalmazott mellérendelô viszonyok - a testközeliség, a színpad és a nézôtér közötti feszültség megszúnte, a fent és a lent tereinek az átjárhatósága - úgy számoltak fel bizonyos korlátokat, mint a Pápai Zsolt nyomán fentebb bemutatott esztétikai megoldások: a disszenzus nyelvét beszéltetô alkotásmód a meglévô hierarchiákat belülrôl bomlasztotta.

A koncertélmény megidézése a résztvevôk motivációinak és szociokulturális hátterének az érzékeltetése mellett cselekményvezetési szereppel is bír Xantus filmjében. Méhes Marietta saját hangját a férfiak dominálta underground zenei szcénában találja meg: múvészi személyiségének kiteljesedése ugyanakkor elválaszthatatlan az érzelmi válságtól, ami a férje iránt érzett szeretô felelôsség és a zongoristához kötôdő erotikus vágyódás konfliktusából fakad. Múvészi 
érzékenységét az ideg-összeroppanás egyre fenyegetôbb réme hívja életre; frusztrációkkal teli énekhangját és az elveszettséget tükrözô elôadásmódját a szorongás elidegeníthetetlenül emberi állapotának színpadra viteleként értelmezem.

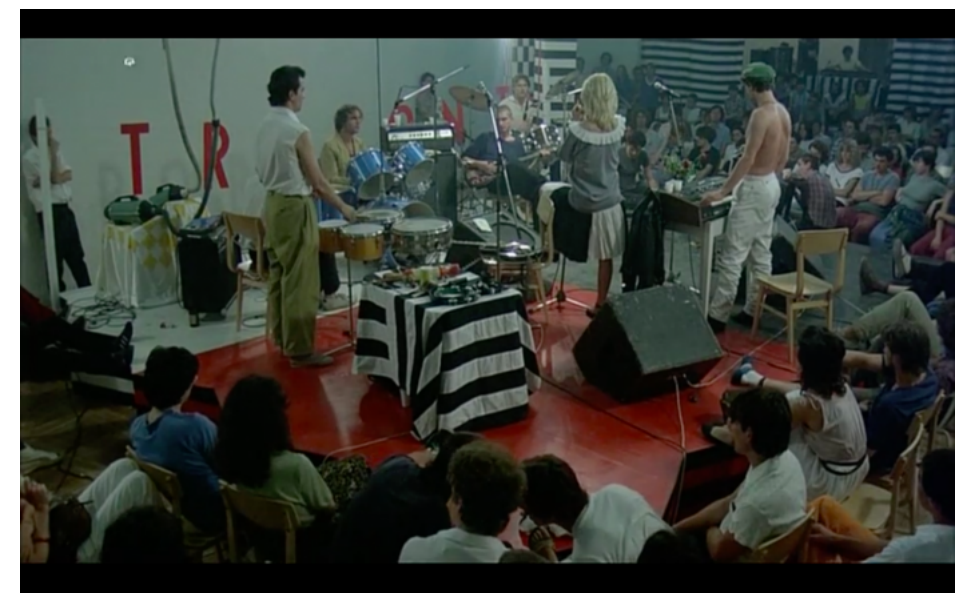

Eszkimó asszony fázik (Xantus János, 1984)

Méhes melankolikus alakítása $A$ kutya éji dalában hasonló érzelmi hasadtságból táplálkozik. Szexuális motiválatlanságtól és általános fásultságtól szenvedô férjétôl elhidegül, az állandó veszekedések elôl, kisfiát hátrahagyva, Budapestre menekül. Az egyik sorsdöntố veszekedés során férjét impotensnek nevezi - „Még megbaszni sem tudsz!” -, ami a maszkulinitás válsága mellett a testi kapcsolatok általános kiüresedettségére is utal. Az új érzékenység filmjeiben a szexuális aktusok kevés örömet kínálnak és animálisak, többek között azért, mert a férfiak rendszerint hátulról, a szemkontaktust ellehetetlenítô és az érzelmességet leértékelô pozícióban teszik magukévá partnerüket. Az intimitást nélkülözô, vegetatív állapotú párkapcsolatból Bódy filmjének hôsnôje a pezsgố budapesti underground világban keres menedéket, és hamarosan a színpadon látjuk viszont, ahol a Bizottság Szerelem címú dalát énekli Wahorn Andrással. A dal eksztatikusan ismételt soraiból - „Már megint itt van a szerelem / Már megint izzad a tenyerem / Köpni kell / Minek? Minek? Minek? / Szerelem, szerelem, szerelem / Köpni kell! Pú!” - teljesen hiányoznak a szentimentális-romantikus felhangok, ugyanakkor a szerelemról olyan megzabolázhatatlan erôként beszél, ami egyszerre indít be és borít ki. Míg a romantikus költészetben és a könnyúzenei dalokban a szerelem egy széthulló világban a személyes integritást biztosító érzelemként jelenik meg, addig itt a szétforgácsolódó én alapélményeként. A szerelem szokatlan tapasztalatát erôsíti a fokozatosan hisztérikussá váló éneklés és egyre vadabb színpadi mozgás, ami vokális orgazmusban (vagy éppenséggel halálhörgésben) éri el a csúcspontját. Az előadás felfokozott hangulatát sem figyelmen kívül hagyva úgy fogalmazhatunk, hogy a Szerelem címú dal nem szerelemellenes, hanem szerelmesdal-ellenes.

A színpad szubverzív használatára további példát kínál a Jégkrémbalett hosszú koncertjelenete, melyben az elôadók inkább egy bohém házibuli vendégseregének, semmint zenészeknek tûnnek. Egyesek korcsolyában lépnek fel, mások üres üvegek körül táncolnak és csak az énekrészekre ugranak oda a mikrofonokhoz, efZámbó István a színpadon fekve monologizál, miközben feLugossy lovaglópálcával csapkodja meztelen fenekét, egy szám erejéig pedig Wahorn kislánya is 
megjelenik a színpadon. A kaotikus koreográfia, az improvizatív elemekben tobzódó elōadásmód, valamint az egyetlen rövid strófa ismétlésén alapuló, végtelenségig elnyújtott dalok nyíltan szembementek a szórakoztató slágerek képviselte könnyúzenei irányzattal, és változtatták a koncerteket infantilizmust sem nélkülözô avantgárd happeningekké.

Míg Xantus János Eszkimó asszony fázik címú filmje Méhes Marietta énekesi pályafutásának csúcsát, majd Amerikába távozását örökíti meg, a Rocktérítô Pajor Tamás identitáskeresésének a legdrámaibb fejezetébe kínál bepillantást. A Neurotic frontemberének kompromisszumok nélküli életérôl szóló filmet végül maga az élet rendezte: Pajor megtérése és radikális életmód- és értékrendváltása. A magyar underground rockzene koronázatlan királyának dalszövegei zenészek egész generációit ihlették meg, míg Pajor zabolátlan önpusztító életvezetése (Gémes János Dixie-t leszámítva) legfeljebb az angolszász rockzene világhírú és korán elhunyt sztárjainak devianciájához volt mérhetô. Xantus a következôképpen jellemzi a fôszereplő személyiségének átalakulását: „Elő́tte mintha nem talált volna kapaszkodókat, mintha a semmit markolászta volna, most pedig nagyon biztos és világos, egyértelmú tájékozódási pontja van, amihez képest mindent viszonyítani tud. Ugyanakkor ez együtt járt személyiségének elszegényedésével” (Barabás 1988: 22). A tévelygố Pajor egyszemélyes intézmény volt, a marginális-disszenzuális rockzene megtestesülése, aki tudatosan építette sztárimázsát, és aki lebilincselô színpadi jelenlétével komolyan feladta a leckét az államilag támogatott szakmának.

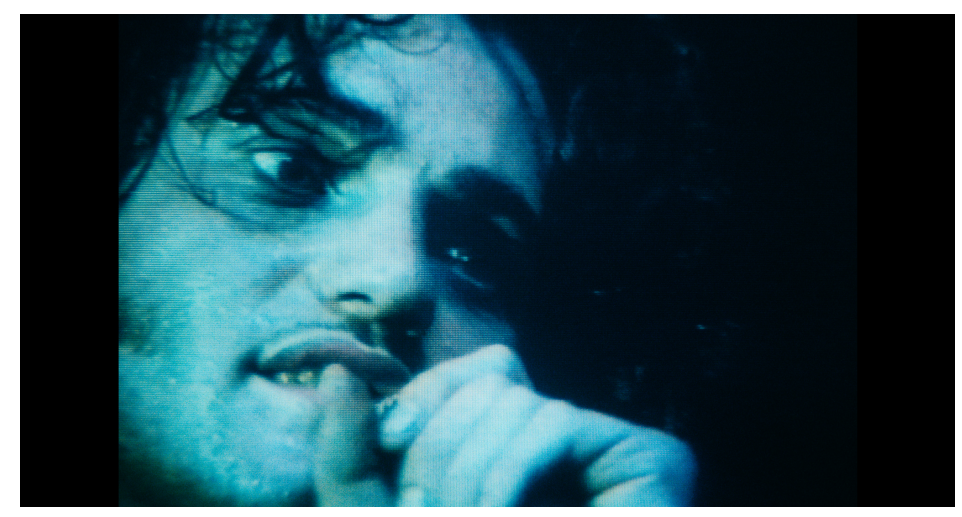

Rocktéritố (Xantus János, 1988)

Xantus filmje a rock iránt végletesen elkötelezett emberról szól, olyasvalakirôl, aki ösztönösen ráérez a rock and roll tömegmozgósító erejére, a zene közösségformáló lehetôségeire, ugyanakkor pontosan érti, hogy ehhez elkötelezett rendezvényszervezôkre, profi hangosításra és fénytechnikára van szükség. Pontosan azokra a technikai és technikusi erőforrásokra, melyet csak a nyilvánosság underground zenekaroktól megtagadott szegmense élvezhetett, és amelynek élvezete során elveszítette kapcsolatát a rockmentalitás gyökereivel. Pajor disszenzusa a képmutató magyar popszakmával való egyet nem értést képviselte, mert olyan tehetségből fakadt, ami nem mintákat imitált, hanem eredetit teremtett, ami világviszonylatban is jelentôs látomásokat és nemcsak utánérzéseit/utánérzéseket foglalt zenébe. A gyermekcipôben járó zeneipar mellett a hazai politikai és társadalmi viszonyok is érvényesülése ellen dolgoztak. Xantus szavaival: „Magyarország nem alkalmas arra, hogy itt az igazi rock meg tudjon élni. Mert az az 
ember, akiból olyan indulattal robbannak ki a dolgok, hogy még a hallgatóság utolsó soraiban is erôsen hallatszanak, az nem tud olyan környezetben létezni, ahol tíz vagy tizenegy órakor lekapcsolják a fókapcsolót, mert a környék lakói már nyugovóra tértek. Az igazi rock and roll olyan fokú devianciával jár együtt, amit egy korán fekvô ország sajnos nem tud tolerálni” (Barabás 1988: 24). A Rocktéritố kínálta összetett személyiségportré ugyanakkor azt is világossá teszi, hogy az underground zenészek közül Pajor viselte a legnehezebben az alternatív nyilvánossággal járó láthatatlanságot és marginalizáltságot. Víg Mihály Európa kiadó címú dalának sorai - „Olyan már mint egy menekülttábor / mindenki itt van, aki nem elég bátor" - pontosan ragadják meg Pajor viszonyát a szubkultúra jelentette gettóhoz. Megtérésével kilépett innen, de talán nem úgy, ahogy tervezte. Zúrös múltjának megtagadásával kétségtelenül egy új közönség elött vált legitimmé, de a Hit Gyülekezet rocktérítójeként ugyanúgy rétegzenét játszott, mint korábban. A film zárójelenetének tanúsága szerint céljai részben teljesültek: Pajor szó szerint eljutott a nyilvánosság elé, és keresztény rockdalokat játszó Ámen nevú zenekarával Budapest zsúfolt utcáján hétköznapi ruhában, jól fésülten és frissen borotválva hétköznapi emberek elôtt zenélt. A jelenet azért is dokumentumértékú, mert itt látunk elôször átlag magyarokat találkozni az underground zeneiszövegbeli hagyatékával, reakcióikból pedig az olvasható ki, hogy ilyet még soha nem láttak és hallottak. Ezzel tulajdonképpen a disszenzus egyik alapcélja teljesül.

A fentebb vizsgált filmek zenészszereplók és az alternatív kultúra alakjainak vonatkozásában tárgyalják az érzékenységet elóhívó identitásválságot. $A$ kutya éji dala a szerzôi önreflexivitás ritka példája, merthogy Bódy egy titkos szektához tartozó álpapot alakít. Talán nem véletlen, hogy lebukásakor egy klubhelyiségben a Bizottság Kamikázé címú számára táncol vadul a színpadon, abban a térben, amely az emberi állapot lecsupaszításának a helyeként került ábrázolásra filmjében. Fontos többletjelentéssel bír a jelenet, a hosszú karjaival eksztatikusan csapkodó Bódy kiesik a szerepéból, és valami elmondhatatlant próbál kommunikálni. A többletjelentés 1999-ig rejtve maradt: ekkor derült fény a rendezô magyar és keletnémet titkosszolgálattal való kollaborációjára. Ez az információ a film újraértelmezését is lehetôvé tette, Kovács András Bálint például úgy jellemezte az alkotást, mint egy „rejtett önvallomás”, „palackba zárt üzenet” (Kovács 2002: 278), ami Bódy öngyilkosságát is új megvilágításba helyezheti. További beszédes adalék, hogy amikor Bódy belép a helyiségbe, a rádióban egy róla szóló, felkutatásában a lakosság segítségét kérô rendôrségi közleményt hallunk, majd a pultos kezében lévô napilapban az „Eltûnt álpap nyomában" kezdetú újságcikk nagyközelijét látjuk. A film hagsúlyosan a nyilvános szféra hivatalos médiumaihoz kapcsolja a rendezô rejtôzködő, enigmatikus identitásrészét. Egy gyors telefonhívás után a pultos odamegy Bódyhoz, és a következó párbeszéd zajlik le közöttük:

\footnotetext{
- Maga pap?

- Nem.

- Felismertem!
} 
- Ha felismert, akkor már pap vagyok.

- Csak azt akartam mondani, hirtelen úgy meglepôdtem. Meneküljön! Hívtam a rendőrséget!

A szembesítést és leleplezést rezignáltan nyugtázó Bódy félretolja a férfit, és karjaival hevesen csapdosva tovább táncol, miközben a Bizottság-dal alábbi sora hangzik el: „1993, augusztus 13-a nem biztos, hogy péntek / Egyedül vagyok, nem biztos, hogy élek." Rejtett kitárulkozás mellett van itt más is: önbeteljesító jóslat. 1985. október 24-én önkezével vetett véget életének. Csütörtökön.

\section{A videoklip transzgresszív politikája}

Részben az alacsony költségvetésnek, részben a szerzői koncepciónak köszönhetôen az új érzékenység egynémely filmjéból hiányoznak a koncertjelenetek. Ide tartozik $A$ pronuma bolyok története és az Ex-kódex, két alkotás, melynek rendezői vagy a természetes helyszíneken vettek fel dalokat, vagy jeleneteket írtak kész zenékhez. Az említett két filmen túl a Jégkrémbalett bizonyos jelenetei a nyolcvanas évek ikonikus underground dalainak „videoklipjeiként” jelennek meg a közösségi médiában. Wahorn filmjének az esete egyedi, hiszen/mivel a videotechnikát koncepciózus módon használja, és a koncertfelvételeket különbözó helyszíneken készített mozgóképekkel és archív anyaggal vegyíti. A film második felét kitöltố videoklipszerú montázsszekvenciában a korai videomúvészek körében elôszeretettel használt szolarizáció technikája dominál, ami bizonyos színek túltelítésével olyan hatást kelt, mintha a kép „nukleáris energiát" sugározna ${ }^{\left[{ }^{[9]}\right.} \mathrm{A}$ kép technikai manipulációjával elért földöntúli hatás legékesebb példája a Nói agyveló, ami széles tematikai spektrumon elhelyezhetố képeket (agyvelórôl, kartondoboz telefonkagylóval a Balatonba ugráló és néptáncoló zenekartagokról készült felvételeket) helyez egymás mellé. Minimalista képstilisztikai eszközök jellemzik a Kokó múvésznő és feLugossy duó énekelte Milarepaverziót, amely igencsak furcsán tiszteleg a tibeti buddhizmus spirituális önmegvalósítást hirdetố vezetôje elôtt: az értelmetlenség határait feszegetô, erôs gesztikulációval énekelt szóvirágok, a kép elôterében elegáns ruhákban iszogató zenészek és a hátterében fürdōzô nyaralók ilyen elrendezésben szürreális hatást keltenek.

A Bizottság videóiban megjelenó giccs, a kozmopolita-bohém díszletek, a furcsa helyzetekben (iszapdagonyázás, telefonnyaldosás) ábrázolt zenekartagok és az intellektuális erőfeszítésre sarkalló, de tulajdonképpen önkényes képasszociációk a provokáció gazdag tárházát kínálva fejezték ki a zenekar Preparababra kabaré címú dalában nyíltan megfogalmazott életfilozófiáját: „A jó ízlés Drágám az nevetséges / a botrány, a botrány az egészséges”.

A zenei videók hagyományos formáitól (elöadás-központú, cselekményközpontú és konceptuális) eltérô feldolgozásmód - a fentebb vizsgált szubverzív színpadhasználathoz hasonlóan - a videoklip transzgresszív politikáját helyezte elôtérbe. Ez a helyzet $A$ pronuma bolyok története 
Az erôs dobritmust felerôsítô, szertartásos törzsi kántálást utánzó háttérvokál és a Menyhárt Jenô által frusztráltan üvöltött ismétlődô sor („Ez egy igen-igen kemény, kemény világ”) Budapest zsúfolt utcáinak képeivel párosul. Az autó hátsó szélvédójén keresztül, ugráló képkivágásban megjelenô város a fenyegetô bizonytalanság hatását kelti. A hátrafelé, semmint elôre nézô kamera, valamint a nézô számára ismeretlen úti cél felé haladó autó megtagadja a nézôtôl az irányítást, vagy legalábbis annak az illúzióját. A kis Valentino fôhôsének céltalan útjait megidézô bolyongás nem az iránykeresést, hanem az irányvesztettség generációs életérzését közvetíti, akárcsak az értelmetlen szavak és a dalszöveg ellentmondásossága: „Túl sok a rendôr / túl sok a spicli / kevés a kurva / kevés a strici / kevés a rendôr / kevés a spicli / túl sok a kurva / túl sok a strici”. Kép és szöveg egymást erôsítve tagadják meg a nézôtôl az értelemadás biztonságot teremtô pozícióját, mely helyett a zaklatottság zsigeri megélését és az értelemvesztés keserú érzését kényszerítik a közönségre. Itt mégis más a helyzet, mint a Bizottság-dalok és -klipek önkényes jelentéshalmozásának az esetében, hiszen film és zene összehangolt munkájának eredményeként tapasztaljuk meg a válságállapotot, azt, hogy semmi sincs rendben. A klip nem firtatja a válságállapot okait, Jeleshez hasonlóan megelégszik annyival, hogy érzéki-intellektuális benyomásokat rögzítsen, a lefoszló jelentést annak karcosságában mutassa fel: Menyhárt elkeseredett üvöltéseként és az idegesen rángatózó képként. A Rocktéritố egyik jelenete nyíltan reflektál Szirtes filmjének imént tárgyalt szekvenciájára. Ott is egy autó, pontosabban egy rendôrautó hátsó üléséról látjuk Budapestet. A kamera már nem hátrafelé nézve, hanem az ajtóüvegen keresztül és szabadon svenkelve mutatja a várost ${ }^{[10]}$, ennyiben nem a kiszolgáltatottság és irány(ítás)vesztettséget érezzük a jelenet meghatározó motívumának, hanem a keresést. Míg az Európa kiadó az $M$, avagy egy város címú dalában Frinz Lang klasszikusára utal, ez a jelenet talán Walter Ruttmann Berlin, egy nagyváros szimfóniájára (Berlin: Die Sinfonie der Großstadt. Walter Ruttmann, 1927) asszociál: Budapest a rap ütemes ritmikájában, játékos mondatszerkesztéseiben és a flaszteren pattogó szóképeiben keresi új „szimfóniáját”, új zenei identitását. Xantus szerint meg is találja; a klip zenéjét, a Neurotic Brék címú számát méltán nevezhetjük a nyolcvanas évek underground himnuszának.

Az Ex-kódex színészeinek többsége, akárcsak rendezôje, zenész, ami a film szubkulturális kötôdéseit és a közösségi filmkészítés iránti elkötelezettségét egyértelmúvé teszi. ${ }^{[11]}$ A forgatásban részt vállaló Kontroll csoport tagok és más underground figurák nagy száma ellenére a film Bárdos Deák Ágnes elôadásában a Megvan mindenem címú számot és két Víg Mihály-kompozíciót tartalmaz. Ezek közül az Ellenốr úr kérem címú dal jelenetében újra egy közlekedési eszköz jelenik meg, konkrétan az 5-ös számú BKV-járat, amire egy vak férfi száll fel, és bár többen felajánlják ülôhelyüket, ő konzekvensen visszautasít mindenkit. Mint késóbb kiderül, azért, mert ô a buszsofốr. Ez a minitörténet újabb utalás a kor reménytelenül ellentmondásos viszonyaira. Víg Mihály Állatok címú dalának akusztikus átirata a képi minimalizmus eszközeivel kiegészülve magáról az underground létrôl beszél. 
A fix kameraállásból egyetlen beállításban fényképezett jelenetben két félmeztelen férfit látunk (Víget és Gémest), akik másnaposságukat némi töménnyel, cigarettával és kvarclámpával kezelik. Míg a csendes hétköznapok családias hangulata és a képnyelvi realizmus a házivideók stílusát elôlegezi meg, addig a férfiak falra vetüló árnyékában kirajzolódó szexuális pozitúra a kompozíció megtervezettségére utal. A meztelenség, a lágy énekhang és az árnyékok félreérthetetlen homoerotikus jelentéssel ruházzák fel mind a testeket, mind a teret, mely utóbbi az érzéketlen külvilággal szemben védelmet kínál, ugyanakkor az identitás rejtôzködő [closeted] voltára utal. Az érzékenység belsô világát líraiság, fantasztikum és békétlenség uralja. A dal a fenséges filozófiájára („Most csukott szemmel is látom / Hol van ami elveszett), az Alice csodaországban lakóinak (Káró dáma, Treff bubi és Kör király) szürreális világára és az Állatfarm politikai allegóriájára („De ez az állat két lábon áll / két lábon áll és orra remeg / ez az állat szemez veled”) is utalva beszél egy életérzésrôl. Az a mód, ahogy Víg a nyolcvanas évek Magyarországát egy látomásos keretbe helyezi, a mindennapi élet fantasztikuma iránti elkötelezettségét érzékelteti. Figyelembe véve továbbá azt, hogy ez idô tájt a Trabant zenekar házistúdió-zenekarként definiálta magát, és a nyilvánosság torz struktúrájával szembeni ellenérzéseit kifejezve nem lépett közönség elé, a klipet egy bujkálásra ítélt szubkultúra önreprezentációjának tekinthetjük.

\section{Posztszenzibilitás: az új érzékenység utóélete}

A rendszerváltást követôen a budapesti underground zenei szcéna a politikai elitváltás, a piacgazdasági szemléletváltás és az új hullám lecsengésének köszönhetôen marginális pozícióban maradt, ugyanakkor rétegközönségét megtartotta. Egy teljesen új világ építésének az ígérete és a nyilvánosság államhatalmi eszközökkel való felügyeletének visszaszorulása megkérdôjelezte a disszenzuson nyugvó neoavantgárd múvészi gyakorlatok legitimitását, ami magyarázatot ad arra, hogy az új érzékenység politikai-társadalmi kommentárt is megfogalmazó filmjeinek alkonya miért a nyolcvanas évek végére esik.

Tarr Béla Kárhozat címú filmjében Kamondy Ágnes lép fel a - süllyedô világ képzetét keltô -Titanik bár színpadán.

A rendezô stiláris kézjegyét jelentố hosszú beállítás dominálta jelenetben Víg Kész az egész címú melankolikus dalát adja elố az Európa kiadó valahai billentyúse és basszusgitárosa. A dalba foglalt kétségbeesettséget és illúzióktól mentes léttapasztalatot a lassan mozgó kamera és az elvontság jellemezte fekete-fehér kép emeli kozmikus szintre. Az énekesnô elhagyatottságot tükrözô, mégis finom testtartása (a színpad oldalának támasztott homloka, behunyt szeme és cigarettát tartó ujjai) átlényegítik a teljes leépülés feltartóztathatatlanságát megéneklô szöveget:

Kész az egész 
Mindennek vége,

Vége már és

Nem lesz másik

Nem lesz jó

Soha már

Soha talán.

Kamondy sötét háttérbôl kitûnô alakja, majd arca válik a vizuális jelentés alapjává. Az arc színpaddá válik, a pózaitól megfosztott, lemeztelenített lét színpadává, de azzá az elidegeníthetetlenül emberi jelenlétté is, amely felülemelkedik a szavakban megidézett nihilizmuson. E felülemelkedés mentes az optimizmustól, nem néz a jövőbe, ugyanakkor nem nyugszik bele abba, hogy a pusztulásban a múvészet véget ért, hogy a múvészet vége a pusztulás. A dal záró versszakát követố befejez(het)etlen-állhatatos szaxofondallam ezt a benyomást kelti:

Kész, ez kész, nincs vége,

Vége már.

Nem múlhatott el és nem fog

Elmúlni soha már.

Soha talán.

Talán soha már

Kamondy előadásának az érzékenysége más jellegú, de mégis összevethetô azzal, amirôl Wahorn a Jégkrémbalettben a pusztulás elôtti végsô megvilágosodásként beszél. Az énekesnôt megszólaltató érzékenység posztszenzibilitás: a végsô pusztulás utáni megvilágosodás. Tarr Kárhozattal kezdôdô szerzôi ciklusa a pusztulás utáni filmmúvészet, a lecsupaszodottsággal, mozdulatlansággal és elhalványultsággal való állhatatos szembenézés mozija. Az új érzékenység egy fontos tekintetben továbbél Tarr fekete szériába sorolt filmjeiben, melyek - Pólik József megfogalmazásában „egyrészt rögzítik az összeomlás tényét, másrészt megmutatják az összeomlott egzisztencia amorális hétköznapjait - azt, hogy mi maradt az emberból, az emberi értékekból" (Pólik 2013: 122). A marginalizáló és kiszolgáltatottá tevô világ nem elmúlik, pusztán levedli konkrét politikai és társadalmi meghatározottságát. Az underground zenészekhez hasonlóan Tarr is konstatál; mondandóját a kilátástalanság kozmikusabb tapasztalatához igazítja, egy olyan világéhoz, amelyben a szubverzív disszenzus helyett már csak a reménytelenség vihetô színpadra.

A Sốn és Grósz, Ács Miklós 1988-as non-budget filmje a szubkulturális ábrázoláson keresztül kapcsolódik az új érzékenység filmjeihez. Ács ugyanakkor a periféria perifériáján helyezkedik el: 
teljesen amatôr, nem tartozik a zenei underground belsô köreihez, és nem támaszkodik annak összetartó közösségére, személyes kreatív energiáira. Filmjéből hiányoznak az alternatív zenészek, egyedüli színésze a szerzôtársa, Rinya Andrea, akivel egy panellakótelepi tízemeletes ház alapvetô komfortokat nélkülözô szárítóhelyiségében lakik együtt és forgat. A Sốn és Grószban megjelenô generációs érzés és perifériatapasztalat egyfelól lokális (mert bár nem zenészként, de Ács is a budapesti underground zenei élet holdudvarában szocializálódott), másfelól egyetemes, mind a nonkonformizmus hangsúlyozásában, mind a javak felhalmozását hirdetố fogyasztói társadalom kritikájában. A film angolszász punkzenekarok felvételeit és a Kontroll csoport dalait vegyítő zeneválasztása Ács kulturális kozmopolizmusát fejezi ki. Míg a szubkultúrák közös nyelveként megjelenô punkzene a Keletet és Nyugatot elválasztó politikai határok mesterséges voltára -mutat rá, addig a zenét hitelesítő életérzés a disszenzus jelentését tágítja ki. A Sôn és Grósz nem a puha diktatúrában megélhetô elmagányosodásról, hanem az életmódok, értékpreferenciák és normatív mentalitások kényszerítô erejéról beszél. Más szavakkal: a Jégkrémbalettel szemben Ács nem Békásmegyer rabszolgatelep voltát, hanem a panellakótelep mint a modern életformát domináló, az emberi kapcsolatokat elsorvasztó tér diktatúráját hangsúlyozza. A szocialista modernizáció térbeli allegóriájának tekinthetô lakótelepet a film szereplôi nomádként, az otthonhoz kapcsolódó civilizatorikus értékektôl megfosztva lakják. A bútorok, fôzési, fürdési és higiénés lehetôségek nélküli helyiség, melyben a puszta létfenntartás is folyamatos improvizációt igényel, az utópikus építészeti térbe ékelôdô posztapokaliptikus szubkulturális térként kerül ábrázolásra. A komfortos magánszféra eltûnésével párhuzamosan mégis létrejön egy intim magánvilág, melynek líraiságát, melankóliáját, konfliktusait és energiáit elsôsorban a dalok közvetítik. A zene a befelé fordulás ágenciája lesz, a világ iránt érdektelen én a zenéhez mint világformáló erôhöz fordul.

Monori Mész András Meteójában a zenei underground számos alakja tûnik fel: Kistamás László az egyik fôszerepben, feLugossy László és szintén a Bizottságban zenélô Kukta Erzsébet a klubjelenetben a színpadon, míg Másik János a film zeneszerzőjeként. Emellett a társadalmiegzisztenciális bizonytalanságok a fentebb elemzett filmekhez hasonlóan a Meteóban is központi motívumként jelennek meg. A kelet-európai régióban lezajlott politikai változásokra aktuálpolitikai utalások nélkül reflektáló alkotás nem véletlenül volt az 1990-es év legsikeresebb filmje 57.000 nézôvel (Varga 2016: 133). Mész látomásában a posztapokaliptikus a posztkommunista szinonimájaként jelenik meg. A színpadon fellépô ipari avantgárd zenekar érzékelteti az értékválság valódi mértékét. Az ipari zene esztétikája kérdőjelezi meg a legnyilvánvalóbb módon a rockzene szépség és harmónia iránti elkötelezettségét. A fémes, torz hangzás és a hiányzó dallamosság illik a film zord ipari környezetéhez, a zeneválasztással Mész leginkább a posztapokaliptikus lét szorongásait és irányvesztettségét hangsúlyozza. A filmben szereplô ipari zenében nincs érthetô ének, csak kántálás, talán mert szavak nélkül is érti mindenki a világ széthullottságát. A zenészek között, illetve a színpad és a nézôtér között semmiféle kommunikáció nincs, mintha mindenki gépiesen egy elôre meghatározott parancssort hajtana végre. Ezt sugallja a közönség tánca, mely a tagok összehangolt, elôre-hátra szökdelô mozgásában leginkább egy fogaskerékláncra hasonlít. Mozgásuk és egységesen fekete ruházatuk helyettük kommunikál, de mégsem mentes az érzékenységtôl. Van valami rituális ebben a gépiességben, 
mintha az uniformizáltságban kiteljesedni képes történelmi kor temetési szertartása zajlana a szemünk elốtt. Az ipari zene koreográfiája egy olyan világ temetését idézi, ami magát az embert temette maga alá.

A Meteo posztapokaliptikus világa a széthullásra adott egyéni reakciókban és identitásstratégiákban válik kelet-európaivá. Egyesek alkalmazkodnak a farkastörvényekhez és helyi tudásokra támaszkodva próbálnak meg túlélni, mások kivándorolnak abba a másik világba, ahová mindig is vágytak. A Kistamás alakította Felhôcske saját fantáziavilágába vonul vissza. Ezek az identitásstratégiák nemcsak hiteles képet adnak a régió posztkommunista idôszakáról, de a budapesti underground tagjaira is érvényesek. Számos zenész, többek között Hegedûs Péter, Molnár Gergely, Méhes Marietta, Menyhárt Jenő, Kukta Erzsébet, Wahorn András hagyta el Magyarországot, ki rövidebb, ki hosszabb idôre. Az itthon maradtak vagy visszavonultak a zenéléstôl, vagy visszavonultan folytatják zenei tevékenységüket. A tömegkultúra farkastörvények uralta fôsodrához senki sem csatlakozott.

\section{Konklúzió}

Az új érzékenység filmjeit manapság kultusz övezi, és bár a filmek többsége soha nem került kereskedelmi forgalomba, a gyatra minőségú kópiák ugyanúgy terjednek kézról kézre, mint az újhullámos zenekarok felvételei a nyolcvanas években. Persze a kultusz nem a partizánterjesztésből, sokkal inkább egy erôs generációs nosztalgiából fakad, abból a meggyôződésből, hogy a későszocialista underground zenekarok a maiaknál autentikusabban képviselték a rock and roll életérzést, melyet az itt vizsgált filmek is közvetítettek. Ezt a nosztalgiát lehet élni, vagy meg lehet kérdôjelezni, ugyanakkor nem kétséges, hogy az underground zenekarok koncertjeire járók nem egyestés szórakozást kerestek, döntésük disszenzuális identitásukból is fakadt, és azt is kifejezte. Olyan közegbe vágytak, ami kívül esett a fennálló államhatalom biztosította láthatóságon, ugyanakkor a kirekesztettséget megalapozó és érvényesítô logikát megkérdôjelező vitahelyzeteket és ágenciákat teremtettek. Az érzékelhetôség hallgatólagosan elfogadott (konszenzuális) alakzataira, csatornáira, törvényeire vonatkozó rancièrei fogalomból, az érzékelhetô felosztásából kiindulva ennek a szellemi beállítódásnak és közegnek a természetrajzát teszik a filmek olvashatóvá.

Az avantgárd/újhullámos zenekarok vitahelyzeteket teremtő, a könnyúzenei elôadás és általában a rock and roll szokásos funkcióját és természetes rendjét megkérdőjelező új érzékenységét három megvilágításban elemeztem. Egyfelôl az identitásválság zenei mediatizálására irányult a figyelmem, arra, ahogy a létezô szocializmus nihilista-siralmas közállapotait a zenészek megélték és a rock and roll nyelvét felhasználva (és azt egyénítve) kifejezték. Másodsorban, de az elôzôhöz szorosan kapcsolódva, a disszenzus színpadra vitele érdekelt, a koncertekre jellemzô térhasználati és térpolitikai gyakorlatok, amelyek a nyilvánosság szféráját védő korlátokat feszegették, nem egyszer áthágták. Ezek a transzgresszív aktusok nemcsak közös vonásai voltak a vizsgált szcénának, de alapvetố szerepet játszottak a szubkulturális tapasztalati mezô létrehozásában, hiszen ezekben 
vált megélhetôvé az államhatalmi logikával egyet nem értő periférikus világ közösségi volta. Bár mindvégig a disszenzus filmes ábrázolásai mentén haladt a gondolatmenetem, a harmadik vetülettel egészében a zene képi mediatizálására, a filmekben szereplô videoklipszerú szekvenciákra koncentráltam. Ezek a közérthetôség és a közízlés elfogadott formáit provokáló, azokból magukat tudatosan kirekesztô képsorok a diszharmóniát és a jelentések egymáshoz feszülését hangsúlyozzák. Az új érzékenység mozija itt teszi olvashatóvá azt, hogy a disszenzus nem a hatalomból kiszorult csoportok hatalomra jutását, egy újfajta konszenzus megteremtését szolgáló „politikusi” stratégia, hanem a másként hallható és látható, a másként mondható és gondolható iránti elköteleződés politikája. A disszenzus ugyanakkor pedagógia is, ami a Bon bon si bon címú ikonikus Európa kiadó dalszövegét - „a zene nem zene, a szöveg nem szöveg” parafrazeálva azt tanítja, hogy a nem-zene a zene, a nem-szöveg a szöveg, sốt azt is, hogy a nemfilm a film.

1. A szóban forgó zenekarok közül egyedül az A. E. Bizottság (Kalandra fel!, 1983) és az Európa kiadó (Popzene , 1987) kapott szerzódést a Hungaroton lemezkiadó cégtôl. Az utóbbi zenekarnak ugyanakkor a Balázs Béla Stúdió segítségével - egy elkészíteni soha nem szándékolt film álcája alatt - sikerült rögzíteni korai repertoárját. Ezek a felvételek a rendszerváltás után, a Bahia Records gondozásában jelentek meg Love'82 (1982) és Jó lesz nekünk (1984) címmel.

2. K. Horváth Zsolt hasonlóképpen érvel, amikor úgy fogalmaz, hogy „a hely azért volt kulcskérdés a hatalom számára, mert szinte az egyetlen megragadható társadalmi felület volt számára a tartalom kordában tartására" (K. Horváth 2010: 124). Ugyanô mutat rá a korabeli múvelódési központok hagyományos funkcióinak a kiüresedésére és az ebbôll következố identitásválságára: ,[k]lasszikusan anómiás helyzet lépett fel tehát a múvelődési házak ideológiai, múvelôdéspolitikai irányelvei és a társadalmi gyakorlat között, amennyiben az elôbbiek már nem voltak képesek szabályozni, sốt irányítani a társadalom egyes rétegeinek múvelődését, mivel a kultúra fogalma, természete, illetve a kulturális kohézió célja és mikéntje megváltozott" (K. Horváth 2010: 123).

3. Rácz József korabeli helyzetképe pontos összefoglalását kínálja e kettôsség kialakulásának: „, '80-as évek magyar társadalmának szervezódési elve a »diktatúrával« szemben/alatt/mellett szervezôdố társadalmi szféra. Ez a szubtársadalom, miként a szubkultúrák sem, maga sem rendelkezett kiépült közösségi, érték- és szervezetrendszerrel. Ezt a diktatúra meggátolta. A diktatúra »lágyságából« következett azonban, hogy intézményesülési folyamatok a legkülönbözôbb szférákban egyáltalán elindulhattak. Maguk a tárgyalt ifjúsági szubkultúrák is felfoghatók ilyen intézményesülési, védekezô, átmentô, (pót)szocializálódó kezdeményeknek, melyek ugyanúgy nem tudnak kiépülni és intézményesülni, ahogyan a domináns társadalomban sem" (Rácz 1998: 67).

4. Molnár itt és más írásaiban a „rock and roll” kifejezést általánosságban használja, bizonyos zenei múfajokat és stílusokat ért rajta, elsősorban a Velvet Underground és David Bowie hatvanas-hetvenes években született zenéjét. Az egyszerüség kedvéért én is gyakran pontos megjelölés nélkül használom a terminust, ami ugyanakkor már az új hullám heterogén stílusú zenéire utal.

5. A szembefordulás mozzanatát hangsúlyozza Hegyi Lóránd is az új érzékenység múvészi valóságlátásáról értekezve: „a világot gyökeresen átformálni vágyó heroikus aktivizmustól, az utilitarista-produktivista optimizmustól, a naiv-technicista megváltás tárgyfetisizmusától és esztétikai higiéniájától való eltávolodás, s egyben egy új, személyesen hiteles és befelé építkezô múvészet felé való közeledés körvonalai fogalmazódnak meg” (Hegyi 1983: 18-19.).

6. Beke László egy kerekasztal-beszélgetés során az ideológiavesztettséget történelmileg értelmezi: „Valóban 
eltûnt ugyanis belőlük egyfajta heroizmus, ami mind a nagyjátékfilmben, mind a dokumentumfilmben, mind pedig az avantgardista filmezésben megvolt még a hetvenes évek elsô felében is. Akkor még létezett az a hit, hogy a filmmel mint médiummal létre lehet hozni valamit, és mi majd létre is hozunk valamit. Itt errôl már szó sincs. Marad magának az érzékenységnek a felmutatása” (Szilágyi 1985b: 20).

7. Ezzel szemben Rácz és Zétényi a következóképpen írják le a new wave zenekarok színpadképét: „Minimális a kontaktusuk a közönséggel, de egymás között a testközeliség a jellemzô. A törzsük helyzete elôre-hátra hajladozó, ôk azok, akik a leggyakrabban üldögélnek a színpadon, és sokszor oldalt fordulnak. Náluk a leggyakoribb a keresztbe tett láb, a guggolás. Gyakran emelgetik lábaikat, melyek hajlítottak. Karjaik elől vannak, nyújtottak, extendáltak és feszítettek, ujjaik ökölbe szorítottak. Fejüket előre tartják, szemükkel hunyorítanak: mimikájukat a gondterheltség jellemzi” (Rácz - Zétényi 1998: 39-40.).

8. Egy korabeli beszámoló a Kontroll csoport koncertjét úgy jellemzi, hogy a zenészek színpadi jelenléte „inkább groteszk, mint energikus. A számokat - ritkábban ugyan, de - el-eljátsszák, és nem törekednek az »egy az egyben« megoldásokra, hanem jelzésszerú utalásokkal operálnak. Mozgásuk, interakcióik spontánabbak, nem lekerekítettek, talán szúkebb skálán mozognak. Interakcióik nehezebben dekódolhatók, idézôjelesek, nem direktek, nem »lejátszóak «. Mimikájuk többnyire áttételes, »kikacsintó«" (Rácz - Zétényi 1998: 36).

9. David Bowie magyar undergroundra gyakorolt hatása tagadhatatlan. Ehhez kapcsolódó fontos adalék, hogy a szolarizáció technikája az Ashes to Ashes címú dal videoklipjében jelenik meg elôször, amit a zenész David Mallettel együtt készített.

10. Xantus a Jégkrémbalett kapcsán említett szolarizáció-trükköt is elôszeretettel használja a jelenetben.

11. Ezt bizonyítja Menyhárt Jenô szerepeltetése a stáblistán, holott az Európa kiadó frontembere egyszerú statisztaként, pár másodperc erejéig tûnik csak fel a filmben.

\section{Irodalomjegyzék}

- Barabás Klára (1988): A drog helyére beült a Szentlélek - Beszélgetés Xantus Jánossal. Filmvilág, 31.7. 20-25.

- Csatári Bence-Jávorszky Béla Szilárd (2016): Omega: Red Star from Hungary. In Popular Music in Eastern Europe. Breaking the Cold War Paradigm. Szerk. Ewa Mazierska. London, Palgrave, 14969.

- Gelencsér Gábor (2002): A Titanic zenekara. Budapest, Osiris.

- Hegyi Lóránd (1983): Új szenzibilitás. Budapest, Magvetô Kiadó.

- Jósvai Péter (é.n.): Kutya Éji Dala - Bódy Gábor a gravitáció középpontjában. BodyGabor.hu, URL: https://bodygabor.hu/read/?id=125; 2017.06.15.

1978. Horváth Zsolt (2010): A gyúlölet múzeuma. Spions, 1977-1978. Korall, 39. 119-144.

- Klaniczay Gábor (2003): Ellenkultúra a hetvenes-nyolcvanas években. Budapest, Noran Könyvkiadó.

- Kovács András Bálint (1983): Ipari rituálé és nyelvi mítosz: Beszélgetés Bódy Gáborral. Filmvilág, 26.6. 10-13.

- Kovács András Bálint (2002): A film szerint a világ. Budapest, Palatinus.

- Najmányi László (2010): Spions (elsô rész). Balkon, 18.1. 9-10.

- Pápai Zsolt (2014): Mellérendelő kapcsolatok. Az intézményesülés kérdései és a nyilvánosság problematikája a magyar új érzékenység filmjeiben. In BBS 50. A Balázs Béla Stúdió 50 éve. 
Szerk. Gelencsér Gábor. Budapest, Múcsarnok-Balázs Béla Stúdió, 143-155.

- Peternák Miklós (2014): concept.hu/concept.hu. A konceptuális múvészet hatása Magyarországon. The Influence of Conceptual Art in Hungary. [Kétnyelvú kiadás]. Paks-Budapest, Paksi Képtár-C ${ }^{3}$ Alapítvány.

- Pólik József (2013): A végpont ígézete. In Test és szubjektivitás a rendszerváltás utáni magyar filmben. Szerk. Gyôri Zsolt - Kalmár György. Debrecen, Debreceni Egyetemi Kiadó, 109-124.

- Rancière, Jacques (2011): The Thinking of Dissensus: Politics and Aesthetics. In Reading Rancière . Szerk. Paul Bowman - Richard Stamp. London, Continuum, 1-17.

- Rácz József - Zétényi József (1998): Koncertfotók. Nonverbális kommunikáció a rockkoncerteken. In Ifjúsági (szub)kultúrák, intézmények, devianciák. Válogatott tanulmányok. Budapest: Scientia Humana. 27-40.

- Rácz József - Zétényi József (1998): Rockkoncertek szimbolikája. In Ifjúsági (szub)kultúrák, intézmények, devianciák. Válogatott tanulmányok. Budapest, Scientia Humana. 41-49.

- Rácz József (1998): A ‘80-as évek ifjúsági szubkultúrái Magyarországon. In Ifjúsági (szub)kultúrák, intézmények, devianciák. Válogatott tanulmányok. Budapest, Scientia Humana. 51-69.

- Szemere Anna (2001): Up from the Underground: The Culture of Rock Music in Postsocialist Hungary . Pennsylvania, The Pennsylvania State University Press.

- Seszták Ágnes (1988): Hová vágtáznak a halottkémek? Beszélgetés dr. Grandpierre Attilával. Mozgó világ, 14.7. 86-94.

- Szilágyi Ákos (1985): Milarepaverzió. Kerekasztal-beszélgetés. Filmvilág, 27.7. 18-27.

- Szilágyi Ákos (1985): Az elmesélt én. Az „új érzékenység” határai. Filmvilág, 27.7. 27-29.

- Szốnyei Tamás (1992): Az új hullám évtizede 2. Budapest, Katalizátor Iroda.

- Varga Balázs (2016): Filmrendszerváltások. Budapest, L’Harmattan.

- Vályi Gábor (2003): Közösségi médiumok, globális hálózatok, önszervezô társadalom. a szubkulturális nyilvánosság szerkezetváltozása. In Avantgárd: underground: alternatív. Popzene, müvészet és a szubkulturális nyilvánosság Magyarországon. Szerk. Havasréti József - K. Horváth Zsolt. Budapest-Pécs, Kijárat-Artpool-PTE Kommunikációs Tanszék, 215-223.

\section{Filmográfia}

- A kutya éji dala (Bódy Gábor, 1983)

- A pronuma bolyok története (Szirtes András, 1983)

- Berlin, egy nagyváros szimfóniája (Berlin: Die Sinfonie der Großstadt. Walter Ruttmann, 1927)

- Eszkimó asszony fázik (Xantus János, 1984)

- Ex-kódex (Müller Péter, 1983)

- Jégkrémbalett (Wahorn András, 1984)

- Kárhozat (Tarr Béla, 1987)

- Kis Valentino (Jeles András, 1979)

- Meteo (Monori Mész András, 1990)

- Rocktéritố (Xantus János, 1988)

- Sốn és Grósz (Ács Miklós, 1988) 
(C) Apertúra, 2018. nyár | www.apertura.hu

webcím: https://www.apertura.hu/2018/nyar/gyori-a-mi-agyunk-teves-kapcsolas-az-uj-hullam-

talalkozasa-az-uj-erzekenyseggel//

https://doi.org/10.31176/apertura.2018.4.5

(Q)opertúro 